\title{
THE BALANCE OF PAYMENTS, RUSSIA'S EXTERNAL DEBT AND THE EXCHANGE RATE OF THE RUBLE: A FRAGILE EQUILIBRIUM ${ }^{1}$
}

\author{
A.Bozhechkova, P.Trunin, M.Khromov
}

Russia's balance of payments data for Q3 2015 show a considerable decline in her current account balance. In monetary terms, the decline in imports during Q3 was faster than that in exports (relative to Q3 2014). By comparison with Q2 2015, it even demonstrated a slight increase, notwithstanding the weakening of the ruble in July and August. In Q3, for the first time in five years, Russia saw a noteworthy capital inflow into banks and enterprises resulting from a considerable reduction in the volume of overseas assets (which were sold on a major scale in order to raise funds for looming external debt repayments)and the sale of foreign exchange by the population. On the whole, the trends observed during the period January-September 2015 make it possible to conclude that, unless any new external shocks take place, Russia's current account balance by the end of 2015 will be large enough to guarantee the stability of the ruble's exchange rate against major world currencies in spite of the huge external debt repayments to be made at the end of 2015.

During Q3 2015, exports of goods in monetary terms dropped by $37.5 \%$ on the corresponding period of 2014 (from $\$ 125.7 \mathrm{bn}$ to $\$ 78.5 \mathrm{bn}$ ), including crude oil exports - by $46.9 \%$ (to $\$ 21.4 \mathrm{bn}$ ), and petroleum product exports - by $54.4 \%$ (to $\$ 14.5 \mathrm{bn}$ ). The decline in Russian exports was caused by a considerable drop in prices for energy carriers (during Q3 2015, the average price of oil dwindled by $20 \%$, to $\$ 51.1$ per barrel). Due to the weakening of the ruble and the economic recession, imports of goods declined by $37.5 \%$ (from $\$ 80.5 \mathrm{bn}$ to $\$ 50.3 \mathrm{bn}$ ) over the course of Q3 2015. As a result, Russia's current account balance dropped by $37.7 \%$ on Q3 2014 (from $\$ 45.3$ bn to $\$ 28.2$ bn) (Fig. 1).

It is noteworthy that a comparison of data for Q2 and Q3 2015 shows a rise in imports (+\$2bn) and a drop in exports (-\$12.6bn). It should be noted that the growth in imports in Q3 2015 may have been determined by the strengthening of the ruble in Q2 2015 (the rise in the real effective exchange rate of the ruble amounted to $+20.3 \%$ ) and by the inertial response of imports to the changes in the exchange rate of the ruble, and also by its relative rebound after the sharp drop in early 2015.

As far as the balance of services is concerned, it should be noted that in Q3 its deficit increased, in absolute terms, by $24.7 \%$ on Q2, to $\$ 12.1 \mathrm{bn}$. At the same time, imports of services rose by $12.3 \%$, to $\$ 25.5 \mathrm{bn}$, which can be mainly attributed to the growth in expenditure on international tourism during the holiday season. Exports of services grew only by $2.3 \%$, to $\$ 13.4 \mathrm{bn}$.

The deficit of the balance of payments regarding compensation of employees decreased almost four-fold (in Q3 2014 it amounted to $-\$ 2.7 \mathrm{bn}$ ), which was most likely due to the decrease in the amount of money paid to migrant workers, resulting from a consi-

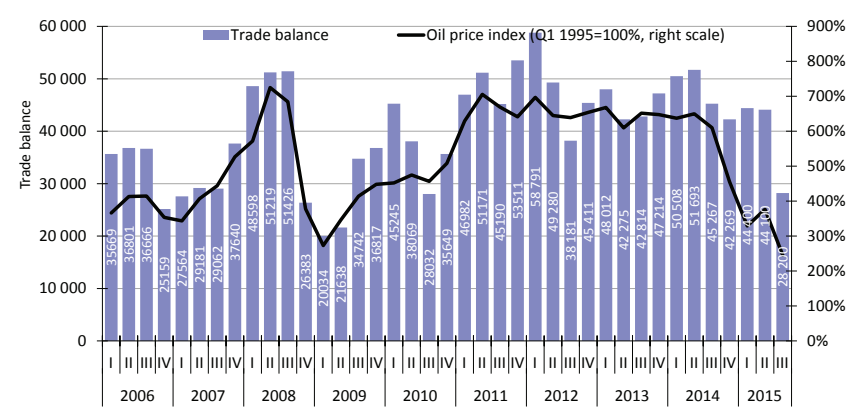

Source: Bank of Russia; estimates by the Gaidar Institute for Economic Policy.

Fig. 1. Russia's Balance of Trade and the Global Crude Oil Prices Index in 2006-2015

derable drop in demand for their services. In Q3 2015, the deficit of the investment income balance declined by $45.5 \%$ on Q3 2014 (from - $\$ 14 \mathrm{bn}$ to $-\$ 7.8 \mathrm{bn}$ ), which was mostly due to a notable decrease in expenditures on external debt servicing (Russia's external debt has significantly decreased).

Thus, in Q3 2015, Russia's current account provided her with a much lesser inflow of foreign exchange than in Q1 and Q2 (\$5.4bn in Q3 vs. \$ 44.5bn in the first half-year 2015), which was due to the resumption of decline in prices for oil and metals, while the volume of imports stayed at the same level as in the first halfyear of 2015.

In Q3 2015, for the first time in many years, the Bank of Russia registered a net capital inflow into the nonstate sector of the Russian economy. This had been seen for the first time since Q2 2010, when Russia's Central Bank registered an inflow of \$3.5bn (Fig. 2).

However, the balance of the private sector's capital transactions with the outside world in Q3 2015 displays a number of specific features. Firstly, in accordance with the Bank of Russia's methodology, the 
resulting figure includes transactions not identified by the regulator ('pure errors and omissions'). For Q3 2015 , such transactions amount to $+\$ 7.1 \mathrm{bn}$, which exceeds the entire net capital inflow into the private sector. This represents a record high for 'pure errors and omissions' registered during one quarter since Q4 2006, when an even higher amount, \$ 7.7bn, had been recorded. This phenomenon can be an indication of a 'clandestine return' of capital previously transferred overseas. Maybe a new trend has emerged, because over the course of the past year and a half, the amount of 'pure errors and omissions' turned out to be positive during five out of the six quarters under consideration. Secondly, the partial reduction in the volume of overseas assets held by the Russian banking sector was determined by the repayment of the Russian banking sector of its foreign-exchange debts to the Bank of Russia. Over Q3 2015, the banks repaid $\$ 6.3 \mathrm{bn}$ of debt to the Bank of Russia from a variety of sources, including their FX-denominated correspondent accounts with the Bank of Russia. As a result, if the banking sector's transactions with the Bank of Russia are taken into account, net capital inflow in Q3 amounted to a mere $\$ 1.8 \mathrm{bn}$.

In all other aspects, the dynamics of financial transactions carried out by Russia's private sector with nonresidents in Q3 2015 mostly matched the trends of the first two quarters of the current year.

Russia's banks continued to repay their main external debt ahead of schedule. Thus, according to the schedule, they should have repaid $\$ 8.2 \mathrm{bn}$ of debt to non-residents during Q3, while in reality, the banking sector' gross external debt (liabilities) declined over the course of that period by $\$ 12.1 \mathrm{bn}$. Most likely, this situation can be attributed to intra-group transaction aimed at optimizing external debt management. In

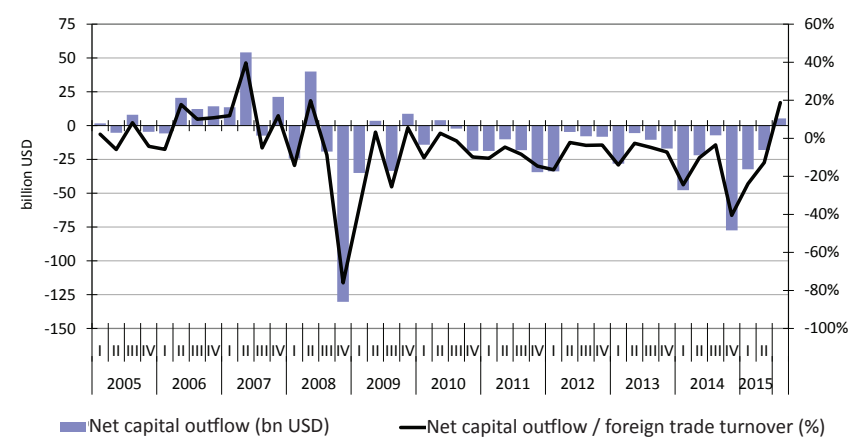

Source: Bank of Russia; estimates by the Gaidar Institute for Economic Policy.

Fig. 2. Net Capital Outflow

from the Private Sector in 2005-2015

the course of such transactions, banks repay the debts due to intra-group creditors, who would then use the received funds to repay the 'real' external debt. During the first three quarters of the current year, Russia's banks reduced the volume of their external liabilities by $\$ 47.6 \mathrm{bn}$, while according to the debt repayment schedule, they should have repaid a mere $\$ 29.1 \mathrm{bn}$ (Table 1).

For the second year in a row, Russia's non-banking sector has been experiencing a sharp decline in the inflow of foreign direct investment (FDI). It should be noted that in 2013, Russian enterprises received $\$ 60.1 \mathrm{bn}$ in FDI (or $\$ 44.1 \mathrm{bn}$, if the transaction between Rosneft and TNK-BP is not taken into account); in 2014, the FDI inflow declined to $\$ 18.5 \mathrm{bn}$, and in the course of the first three quarters of 2015 it amounted to a mere $\$ 6.4 \mathrm{bn}$. The amount of FDI received in Q3 2015 was $\$ 1.5 \mathrm{bn}$.

The other external liabilities of Russia's non-banking sector have been on a steady decline since Q3 2014. However, unlike the banking sector, Russia's

Table 1

DYNAMICS OF NET PRIVATE CAPITAL INFLOWS / OUTFLOWS

\begin{tabular}{|l|c|c|c|c|c|c|c|}
\hline & \multicolumn{2}{|c|}{2014} & \multicolumn{2}{c|}{2015} \\
\hline & Q1 & Q2 & Q3 & Q4 & Q1 & Q2 & Q3 \\
\hline Net capital inflows (+) / outflows into / from RF non-state & -46.9 & -24.1 & -7.3 & -73.4 & -32.4 & -18.0 & 5.3 \\
\hline Banks & -32.6 & -21.4 & 13.3 & -45.4 & -14.2 & -12.7 & -1.1 \\
\hline Liabilities & 0.9 & -7.6 & -11.5 & -19.3 & -24.5 & -11.0 & -12.1 \\
\hline Scheduled repayments & -16.6 & -24.4 & -18.6 & -15.1 & -14.8 & -6.136 & -8.193 \\
\hline Other transactions & 17.5 & 16.8 & 7.1 & -4.2 & -9.7 & -4.9 & -3.9 \\
\hline Assets & -33.5 & -13.8 & 24.8 & -26.1 & 10.3 & -1.7 & 11.0 \\
\hline Other sectors & -14.3 & -2.7 & -20.6 & -28.0 & -18.3 & -5.3 & 6.4 \\
\hline Liabilities & 8.2 & 12.4 & -8.4 & -11.5 & -7.5 & 1.5 & -3.0 \\
\hline Foreign direct investment & 10.5 & 10.6 & -1.1 & -1.5 & 2.4 & 2.4 & 1.5 \\
\hline Other liabilities & -2.3 & 1.8 & -7.3 & -9.9 & -10.0 & -0.9 & -4.5 \\
\hline Scheduled repayments & -37.0 & -17.6 & -37.5 & -41.6 & -21.3 & -15.7 & -18.1 \\
\hline Other transactions & 34.6 & 19.4 & 30.2 & 31.6 & 11.4 & 14.8 & 13.6 \\
\hline Assets & -22.5 & -15.1 & -12.2 & -16.6 & -10.7 & -6.8 & 9.4 \\
\hline
\end{tabular}

Source: Bank of Russia. 
SCHEDULE OF EXTERNAL DEBT REPAYMENTS UNTIL THE END OF 2015, MILLION USD

\begin{tabular}{|c|c|c|c|c|}
\hline & September & October & November & December \\
\hline $\begin{array}{l}\text { Forthcoming repayments, according to trans- } \\
\text { action certificates (main debt amount)* }\end{array}$ & 9,070 & 4,306 & 3,163 & 6,358 \\
\hline $\begin{array}{l}\text { Schedule of Russia's external debt repayments } \\
\text { by other sectors, as of } 1 \text { April 2015: main debt }\end{array}$ & 11,137 & 3,727 & 5,073 & 16,404 \\
\hline Net repayments (according to results of survey)* & 2,398 & 1,764 & 2,903 & 3,293 \\
\hline $\begin{array}{l}\text { Schedule of Russia's external debt repayments } \\
\text { by other sectors, as of } 1 \text { April 2015: interest }\end{array}$ & 1,316 & 1,110 & 882 & 1,373 \\
\hline
\end{tabular}

* based on a survey of 30 biggest Russian companies, whose debt repayments accounted for about $60 \%$ of debt repayments carried out by all non-financial organizations.

non-financial companies have so far managed to refinance most of their foreign debt repayments. Thus, in Q3 2015, although non-financial companies should have repaid $\$ 18.1 \mathrm{bn}$ in accordance with the debt repayment schedule, the volume of their external liabilities (excluding FDI) actually declined by a mere $\$ 4.5 b n$, which means that the companies refinanced their debt repayments or attracted new loans in the amount of $\$ 13.6 \mathrm{bn}$, which was equal to $75 \%$ of the debt repayment that was due in Q3 2015. On the whole, during the first three quarters of 2015, the external liabilities of Russia's non-banking sector declined by $\$ 15.3 \mathrm{bn}$, while, according to the external debt repayment schedule, it should have repaid $\$ 55 b n$ of foreign debt.

On the whole in Q3 2015, the deficit of the financial account amounted to \$2.9bn (vs. \$ 6.0bn in Q3 2014 and \$ 18.7bn in Q2 2015). In Q3 2015, the foreign liabilities of residents declined by $\$ 16.1 \mathrm{bn}$ vs. by $\$ 23.3 b n$ in Q3 2014, while their overseas assets (foreign economic agents' liabilities to Russian economic agents) decreased by $\$ 13.2$ bn (vs. by $\$$ $17.3 b n$ in Q3 2014). Thus, Russia's balance of payments indicates that, in Q3 2015 (like in Q1 2015), economic agents used foreign assets for repaying their liabilities.
It should be noted that, according to the Bank of Russia's assessment of actual foreign debt repayments and the sources thereof, Russia's foreign exchange market is not expected to experience any excess demand for foreign exchange. According to the RF Central Bank's estimates, during the period September-December 2015, out of the $\$ 61$ bn scheduled for repayment, actual repayments may amount to up to $\$ 35 \mathrm{bn}$. The remaining amount is accounted for by intra-group payments and liabilities with a high probability of prolongation and refinancing.

On the whole, the trends observed over the period January-September 2015 have led to the conclusion that, in absence of any new external shocks (including shocks in the energy carrier markets), the year-end total balance of payment for 2015 will, most probably, be sufficiently robust to ensure the sustainability of the ruble's exchange rate against major world currencies. Evidently, the volume of imports in Q4 2015 can be expected to shrink due to the new plunge of the ruble's exchange rate that occurred last summer. This will sustain the current account balance, while the RF Central Bank will probably refinance the yearend REPO debt denominated in foreign currencies, thus relieving the pressure in the foreign exchange market. 